\title{
Controversial alternative diets in the light of current dietary recommendations for overweight and obesity treatment
}

\begin{abstract}
The objective of the study is a critical analysis of the selected alternative diets used in the treatment of obesity inconsistent with the recommended standards, from the perspective of clinical dieticians, based on up-to-date guidelines for dietary management of obesity. Attention was paid to the assumptions of the selected alternative diets, some physiological mechanisms related with their use, as well as the deficit of data pertaining their distant effectiveness and safety. In the context of the current epidemiological situation concerning the prevalence of obesity, it is justifiable to undertake actions aimed at the professionalization of dietary management in obesity, consisting in the application of the treatment methods based on data generated in the EBM paradigm, with a simultaneous indication and criticism of dietary pseudo-therapies with unconfirmed curative value which, in addition, do not guarantee the reduction of the risk of metabolic complications of obesity.
\end{abstract}

Keywords: obesity, alternative diets, dietary guidelines in treatment of obesity, principles of healthy eating.

DOI: $10.1515 /$ pjph-2017-0020

\section{INTRODUCTION}

Obesity has become a significant health problem on a global scale, what implies seeking for the optimum methods for prevention and treatment with consideration of an effective prevention of metabolic complications of obesity. According to the estimations by the WHO, in 2000 , for the first time in the history, there lived worldwide an equal number of the population with an excessive body weight and underweight [1], while the WHO data from 2014 indicate that the problem of excessive body weight worldwide concerned 1.9 million adults, including obesity - 600 million, what means that in recent years the number of obese adults has considerably increased [2]. Therefore, it remains a challenge to develop effective methods for the prevention of obesity on a population scale, as well as schemes for the treatment of obesity which would consider strategies of supporting individuals with the problem of abnormally high body weight, in initiating and maintaining behavioural change related to the mode of nutrition. In the context of an increasing role of an e-health as the platform for the dissemination of knowledge about health and disease not always verified in accordance with the EBM (Evidence-Based Medicine) standard, attention should be paid to the common use by those who are obese concerning widely available guidebooks, books, websites, or newspaper articles promoting dietary management inconsistent with the valid standard of obesity treatment [3]. This is partly the result of the social reaction of stigmatizing obese persons who are perceived as less attractive, less intelligent, and also subjected to social exclusion. The above-mentioned tendency is strengthened by the canon of the beautiful body (cult of slim silhouette) existing in contemporary culture, within the framework of which a specified body image has been identified with the categories of happiness and success. The cultural pressure resulting from this, inclines obese persons to use alternative weight loss diets, implying the risk of development of nutritional deficits and other health complications, including the deterioration of intellectual functions and the increase in the risk of development of dementia, occurrence of affective disorders, an increase in the risk of cardiovascular diseases (CVD), as well as the occurrence of metabolic complications. The frequent problem implied by the use of alternative diets is an insufficient supply of energy, resulting in the reduction of body weight; however, with a simultaneous decrease in resting metabolic rate, which, after discontinuation of the diet and return to previous eating habits, results in the regaining of body weight (so-called 'yo-yo effect') [4,5]. In turn, ketosis caused by the reduction of carbohydrates supply, used in diets such as, e.g. Atkins, Zone, South Beach, Paleo, Dukan, Kwaśniewski, may be dangerous in, among others, patients with arrhythmia, coronary disease and Cushing's syndrome [6]. It is noteworthy that prospective observations of alternative models of nutrition in obesity indicate that the correct control of energy intake plays a crucial role in the conditioning of the effectiveness of dietary management with smaller importance of dietary macro-components [7], which should be individually established for each patient. In the case of the majority of so-called 'wonderful diets', the obtained results are of a temporary character, and the condition for the preservation of the obtained change in body weight is an integration of the mode of nutrition

\footnotetext{
${ }^{1}$ Department of Clinical Dietetics, Medical University of Lublin, Poland

${ }^{2}$ Nutrition Education and Diet Therapy Center, Poland
} 
with the lifestyle of the treated person [7]. In the context of the present epidemiological situation concerning the prevalence of obesity, as well as the relationship with common use of the patterns of dietary management in obesity inconsistent with the standards of medical knowledge, the Polish Association of Dietitians in 2015 published the standards of obesity treatment, based on a critical analysis of the latest data generated in the EBM paradigm, aimed at creation of the model of dietetics based on scientific evidence (evidence-based dietetics practice). The key thesis contained in the guidelines points out that it is not possible to indicate a single weight loss diet that would be optimum for all, and that the plan of dietary management should be of an individualized character, adjusted from the aspect of dietary macro-components to a given clinical situation and the preferences of patients. Additionally, it should be characterized by proven effectiveness and the desired safety profile [8].

\section{Dietary management in body weight loss according to up-to-date recommendations - algorithm for management}

The guidelines for management obesity cover actions in the area of prevention, diagnostic and therapeutic recommendations. In the obesity management guidelines by the American Association Of Clinical Endocrinologists and American College of Endocrinology (AACE/ACE), an elementary principle of obesity prevention was defined in accordance with the theses articulated in The Ottawa Charter for Health Promotion. The creation of pro-health policy is of the utmost importance, favouring a health promoting lifestyle, with consideration of healthy eating patterns in combination with actions aimed at better access to treatment which, as has been emphasized should include the engagement and participation of patients [9]. In the light of guidelines by the Polish Association of Dietitians, an important precondition of the effectiveness of therapy is individualization of dietary management, considering the patient's needs and eating habits, based on the competences and professional experience of the dietician [8]. At the same time, it is emphasized that the treatment of obesity should be provided by interdisciplinary therapeutic teams, based on cooperation between a physician, dietician, physiotherapist, psychologist, nurse and, when needed, other specialists [8].

According to the guidelines of American and European societies (including Polish) dealing with the scope of problems concerning nutrition in obesity [8-11], an obesity management pattern in all adult patients should start with the performance of basic anthropometric measurements, including the BMI and waist circumference. However, with the reservation that the BMI index does not consider inter-individual differences related with gender, age, muscle mass, hydration status, oedemas, large tumours, and sarcopenia [9], therefore, the assessment of the state of nutrition should be expanded by analysis of the body composition, including, among others, an evaluation of adipose tissue content, fat-free body mass, muscle mass, and content of water in the body, performed with the use of the BIA method (Bioelectrical Impedance Analysis) [8-10]. The Polish Association of Dietitians also recommends the performance of biochemical diagnostics with consideration of, among others, lipid profile, parameters of carbohydrate homeostasis (taking into consideration fasting glycaemia, casual glycaemia, HBA1c, and insulin), as well as hepatic aminotransferases, uric acid, creatinine, measurement of arterial blood pressure or, potentially, other parameters in accordance with the physician's decision $[8,10]$. In all patients with excessive body weight, a detailed nutritional and clinical history should be taken, including information concerning socio-demographic characteristics of the patient, concomitant diseases, medicines and/or dietary supplements taken, and habitual mode of eating $[8,10]$. A nutritional interview should be characterised by motivational interviewing and should be conducted in accordance with the principles of the Code of Ethics for Professional Dieticians. The goals of treatment should be established individually and, at the same time, should be realistic. It is recommended to strive towards obtaining a long-term preservation of body weight reduced by $5-10 \%$ in reference to the current body weight, at the same time drawing attention to the fact that in the case of patients with high risk of CVD, even the slightest reduction of body weight by $3-5 \%$ results in metabolic benefits $[8,10]$. The optimum pace of body weight loss should be from $0.5-1 \mathrm{~kg} /$ week during the first 3-6 months of therapy, according to the individual response of the patient to the dietary therapy applied [8-10]. In accordance with the recommendations by the Polish Association of Dietitians, the starting point in establishing an individual demand for energy in obese persons should be the measurement of Resting Metabolic Rate by the method of indirect calorimetry, whereas in the situation of lack of such possibility, the equation by Mifflin et al. may be used [8]. The daily calorie deficit should be from 500 to $800 \mathrm{kcal}$, according to age, current state of health, level of motivation, physical activity, eating habits and preferences of the patient [8-10]. In practice, caloric value of weight loss diet with a moderate energy deficit for women should be approximately $1,200-1,300 \mathrm{kcal} /$ daily, and for men approximately 1,400-1,500 kcal/daily [8]. In justified cases, in patients who are provided care by a therapeutic team, it is possible to apply diets of the VLCD type (Very Low Caloric Diet), where the daily supply of energy does not exceed $800 \mathrm{kcal}$. The indication for the application of such type of diet may be the necessity of quick loss of body weight (e.g. prior to a surgical procedure) $[8,9,12]$. In individuals in whom it is not possible to obtain the loss of body weight by means of dietetic treatment and increased physical activity, pharmacological treatment should be considered, and in special cases - surgical treatment. However, even then proper dietary management and physical activity adjusted to the patient's capabilities are indispensable $[9,12,13]$. Surgical treatment of obesity requires the special surveillance and control of the patient's mode of nutrition during the preparation for surgery, and also after the surgery, due to a high risk of the occurrence of nutritional deficiencies and malnutrition, as well as the yo-yo effect $[8,13]$. The introduction of regular physical activity is an integral element of obesity treatment. With the lack of contraindications, it is recommended to undertake physical activity for $150-420$ minutes or more of intensified physical activity weekly [8-10]. It is worth referring these recommendations to the guidelines by the European Society of Cardiology from 2016, where in the light of CVD prevention, it is recommended to undertake at least 150 minutes of moderate aerobic physical activity a week, or 75 minutes of vigorous aerobic physical activity a week, or a combination of both. The loss of body weight by $5-10 \%$ of the initial weight, resulting from the dietary therapy applied in combination with proper physical activity, decreases the risk of CVD and type 2 diabetes. The recommendations by the ESC emphasize health benefits resulting from the undertaking of physical activity by obese persons even when 
this does not lead to the reduction of body weight. Systematic physical effort results in a decrease in the concentration of $\mathrm{TG}$, and to a small degree, LDL-C in blood serum [14]. The supply of dietary macro-components in accordance with recommendations by the Polish Association of Dietitians in the dietary treatment of obesity should be individually adjusted to a patient, maintaining the principle that protein provides $10-25 \%$ of the total energy needs, fats $-20-35 \%$, while carbohydrates $-45-65 \%$ [10]. Diet should comply with the principles of proper nutrition, and satisfy the demand for mineral components and vitamins (paying attention to the content of calcium, magnesium, iron, zinc, and vitamin D), in accordance with the valid nutritional standards (Polish standards are up-to-date guidelines by the Institute of Food and Nutrition in Warsaw from 2012) [15]. In practice, a weight loss diet usually considers recommendations to increase the consumption of vegetables, seeds of legumes, whole-grain products, as well as milk and low fat dairy products, and fish [11].

\section{Popular alternative weight loss diets - critical analysis}

The dynamic development of e-health implies the creation and popularization of alternative weight loss diets. Based on conversations with practicing dieticians and a review of generally available Internet forums concerning the problem of weight loss, it may be presumed that approaches with a decreased carbohydrates content, compared to the recommendations, enjoy special popularity [16]. These are the following diets: Atkins, Kwaśniewski and Dukan, which were subjected below to critical analysis from the aspect of clinical dietetics. The common feature of the discussed alternative diets is the emphasis placed on the consumption of fat and proteins in various proportions as dominant sources of energy [17].

The main assumption of the Atkins diet is a radical limitation of the carbohydrates consumption in order to metabolize fat accumulated in the body. There are no detailed guidelines concerning the amount of fat and proteins consumed, therefore, according to an individual approach, this diet may be of a high-fat and/or high-protein diet character.

At the first stage lasting for at least two weeks, the supply of carbohydrates should be reduced to the level below $20 \mathrm{~g}$ daily. The duration of this phase is prolonged in the case of lack of expected weight loss. The subsequent stage assumes the consumption of 30-50 g carbohydrates daily, with the amount of carbohydrates consumed being dependent on the outcome achieved. Further slow increase in the consumption of carbohydrates is recommended by $5 \mathrm{~g}$ daily, and subsequently, a weekly observation until obtaining the pace of weight loss on the level of approximately $0.9 \mathrm{~kg}$ per week.

At the third stage, the amount of carbohydrates consumed is individually modified according to the fluctuations in body weight and the set management goals. Similarly to the second stage, a specified pace of increase in the supply of carbohydrates should be applied (an addition of $10 \mathrm{~g}$ of carbohydrates daily, at weekly intervals is recommended until cessation of body weight loss).

The fourth stage consists the application of carbohydrates supply on the level specified at stage three, enabling maintenance of the obtained effect of weight loss. In the discussed approach, the main macro-components of the diet are fats and proteins which may be consumed in any amount and proportions. In effect, this diet considerably differs from the principles of rational nutrition, among others, due to an ex- cessively high supply of fat, cholesterol and proteins, with a simultaneous deficiency of vitamins B1 and B6, folacin, potassium, calcium, magnesium and fibre $[17,18]$. In addition, low levels of carbohydrates intake, which may result in ketosis, are contraindicated in patients with coronary disease and cardiac arrhythmias [6].

The Kwaśniewski diet, also called an optimum diet, is characterized by a higher mean caloric value, compared to the Atkins diet. Moreover, a proportional increase in the intake of fat is assumed, with a lower percentage of proteins and carbohydrates. For this reason, this is a low-carbohydrate and high-fat diet. The menu is composed based on the following proportions of individual nutrients: per $1 \mathrm{~g}$ of proteins there should be $2.5 \mathrm{~g}$ of fat and not more than $0.8 \mathrm{~g}$ of carbohydrates. These proportions considerably differ from the recommendations concerning healthy eating, in the light of which per $1 \mathrm{~g}$ of proteins consumed there should be $0.9 \mathrm{~g}$ of fat and $3.7 \mathrm{~g}$ of carbohydrates. In the majority of studies conducted after 2000 assessing the effectiveness of high-fat and low carbohydrates diets compared to the low-calorie control diet with the recommended amount of carbohydrates, their higher effectiveness was observed. However, this concerned a period of observation not longer than 6 months. Nevertheless, the effectiveness of high-fat and high-carbohydrate diets has not been confirmed in a longer observation. Body weight loss in obese persons who apply this model of nutrition results mainly, similar to the Atkins diet, in progressing appetite disorders related with a high supply of proteins, what leads to a decrease in the amount of energy intake. Thus, it may be presumed that a real caloric deficit leads to obtaining the effect of body weight loss [18-20].

The Dukan diet is a variant of a low-carbohydrate diet. Four phases are distinguished in the application of this approach. The first phase, lasting for 1 week, the so-called attack phase, is characterized by a radical elimination of carbohydrates, and the goal of such management is the stimulation of metabolism, and consequently, an improvement in the effectiveness of adipose tissue reduction. At this stage, it is recommended to consume water in the amount of at least 1.5-2.0 litres daily. The subsequent phase, the so-called cruise phase, may last for several months, according to the established goal of body weight loss. According to the assumptions of the diet, the restrictions obligatory in the first phase should be applied for 5 days, and for the subsequent 5 days introduction into the diet of vegetables, and exclusion of foods rich in starch (potatoes, dried leguminous plants, rice, sweet corn, artichokes, beetroots). This stage is applied until the expected weight loss has been obtained. The duration of the third phase, for the fixation of the effect obtained, is established flexibly: it should last for 10 days per each kilogram of body weight loss. At this stage, it is acceptable to consume whole-grain bread, potatoes and rice, however, not more often than twice a week, fruits with low glycaemic index are also allowed. During the stabilization phase, there are no greater restrictions, with the exception of one day each week when the recommendations from the first, most radical attack phase, should be applied [21].

It should be emphasized that body weight loss accompanying the application of low-carbohydrate and high-protein diets is partly caused by loss of water bound to glycogen as a result of the exhaustion of its resources in the body, and also results, as already mentioned, in the inhibition of appetite due to the excess of proteins intake. Again, attention 
is paid to the metabolic effects of the deficiency of carbohydrates in the diet, which in the mechanism of incomplete metabolism of fatty acids, consist in the development of ketonaemia and ketonuria, and the related metabolic acidosis. Also, during the short period of application of this type of diets, a number of undesirable symptoms were noted on the part of gastrointestinal tract, including constipation, diarrhoea, nausea, as well as weakness and fatigue, headaches and dizziness, sleeplessness, bad breath and increased thirst $[21,22]$.

\section{CONCLUSION}

Dietetic management is an integral and basic element of medical treatment of obesity. Although low-energy diets based on conventional food products are basis for up-to-date nutrition algorithms in obesity, they may also be applied in the management of obesity in the light of the guidelines by the American Association of Clinical Endocrinologists and American College of Endocrinology (AACE/ACE) - they are diets with acknowledged pro-health and prevention advantages, such as the Mediterranean diet, DASH diet (Dietary Approaches to Stop Hypertension), or the vegetarian diet [9]. However, only with the reservation that these diets will be balanced from the aspect of the content of nutrients. Nevertheless, obese persons commonly use nutritional patterns divergent from the recommended management standard (high-fat, low-carbohydrate, fruit, detox, diet consisting of exclusively one food product, starvation diet, and others), entailing metabolic disorders and leading to the occurrence of the yo-yo effect, which in Polish reality is partly the effect of incomplete professionalization in the occupation of dietician, manifested by the lack of legally executed requirements concerning education profile and authorization for using this occupational title. The leading problem associated with the use of dietary pseudo-therapies is their unproven effectiveness in a long time perspective, as well as the lack of data concerning safety as verified in the EBM paradigm [23]. Long-lasting observance of dietary recommendations plays a crucial role in the dietary management of obesity, justified by the regular and frequent contact with a specialist, guaranteeing the preservation of body weight loss obtained [17]. Thus, it seems that one of the most important challenges for contemporary dietetics is the development and implementation of effective management in support of the diet modification and maintenance of the introduced changes, with consideration of the directive for the construction of dietary recommendations realistically possible to perform in the context of a patient's daily life.

\section{REFERENCES}

1. WHO. Obesity: preventing and managing the global epidemic. Report of a WHO Consultation. WHO. Technical Report Series 894. Geneva: World Health Organization; 2000.

2. WHO. 2014. Global status report on noncommunicable diseases; 2014.

3. Gajewska D, Bawa S, Myszkowska-Ryciak J. Strategie leczenia dietetycznego otyłości - czy istnieje optymalna dieta? KOSMOS Probl Nauk Biol. 2010;59(3-4):285-93.

4. Kwiatkowska O, Skop-Lewandowska A. Popularność stosowania diet redukcyjnych wśród kobiet w wieku 19-39 lat. Med Ogólna Nauki o Zdr. 2015;21(3):307-31.

5. Łagowska K, Woźniewicz M, Jeszka J. Ocena wartości odżywczej diet odchudzających zamieszczonych na portalach internetowych. PHiE. 2011;92(4):824-7.

6. Białkowska M. Otyłość. In: M. Jarosz (ed.) Praktyczny podręcznik dietetyki. Warszawa: IŻŻ; 2010. p. 335-41.

7. Sacks FM, Bray GA, Carey VJ, et. al. Comparison of weight-loss diets with different compositions of fat, protein, and carbohydrates. N Engl J Med. 2009;360:859-73.

8. Zespół ds. leczenia otyłości u osób dorosłych Polskiego Towarzystwa Dietetyki: Gajewska D, Myszkowska-Ryciak J, Lange E, et al. Standardy leczenia dietetycznego otyłości prostej u osób dorosłych. Stanowisko Polskiego Towarzystwa Dietetyki 2015. Dietetyka. 2015;8(Wyd. Spec):5-21.

9. Garvey WT, Mechanick JI, Brett EM, et al. American Association of Clinical Endocrinologist and American College of Endocrinology Comprehensive Clinical Practice Guidelines for Medical Care of Patients with Obesity. Endocrine Pract. 2016;22(7):842-84.

10. Yumuk V, Tsigos C, Fried M, et. al. European Guidelines for Obesity Management in Adults. Obes Facts. 2015;8:402-24.

11. Tsigos C, Hainer V, Basdevant A, et al. Postępowanie w otyłości dorosłych: europejskie wytyczne dla praktyki klinicznej. Endokrynol Otyłość Przem Mat. 2009;5(3):87-98.

12. Fried M, Yumuk V, Oppert JM, et. al. Interdisciplinary European Guidelines on Metabolic and Bariatic Surgery. Obes Facts. 2013;6:449-68.

13. Olszanecka-Glinianowicz M. Leczenie farmakologiczne otyłości w świetle aktualnych wytycznych American Association of Clinical Endocrinologists i American College of Endocrinology 2016. Med Prakt. 2017;1:5261.

14. 2016 European Guidelines on cardiovascular disease prevention in clinical practice. The Sixth Joint Task Force of the European Society of Cardiology and Other Societies on Cardiovascular Disease Prevention in Clinical Practice (constituted by representatives of 10 societies and by invited experts). Eur J Prev Cardiol. 2016;23(11):NP1-NP96.

15. Jarosz M. Normy żywienia dla populacji polskiej - nowelizacja. Warszawa: IŻŻ; 2012. p. 86-142.

16. Białokoz-Kalinowska I, Zapolska J, Piotrowska-Jastrzębska J. Kontrowersje w leczeniu dietetycznym otyłości. Pediatr Med Rodz. 2008;4(4):253256

17. Kiedrowski M, Gajewska D. Co powinien wiedzieć lekarz rodzinny o popularnych „dietach odchudzających” i samym odchudzaniu? Med Rodz. 2013;3:95-8.

18. Zachorska-Markiewicz B. Kontrowersje wokół diet. Endokrynol Otyłość Zab Przem Mat. 2005;1(1):9-14.

19. Ruxer J, Mozdzan M, Loba J. Dieta Atkinsa a leczenie otyłości. Adv Clin Exp Med. 2005;14(5):1027-32.

20. Szostak WB, Białkowska M, Cichocka A, et al. Ocena zasadności „Diety Optymalnej” w profilaktyce metabolicznych chorób cywilizacyjnych. Warszawa: IŻŻ; 2004. p. 59-71.

21. Szczuko M, Pieszak N, Jamioł-Milc D, Stachowska E. Dieta proteinowa w świetle zasad racjonalnego żywienia. Analiza składu jadłospisów. Pomeranian J Life Sci. 2016;62(2):31-8.

22. Wyka J, Malczyk E, Misiarz M, et al. Assessment of food intakes for women adopting the high protein Dukan diet. Rocz PZH. 2015; 66(2):137-42.

23. Białkowska M. Leczenie dietetyczne - ciągle aktualna metoda terapii otyłości. Post Nauk Med. 2013;XXVI(5B):38-43.

Corresponding author

Dr hab. Michał Skrzypek

Zakład Dietetyki Klinicznej, Uniwersytet Medyczny w Lublinie

ul. Chodźki 1, 20-093 Lublin,

E-mail: michal.skrzypek@umlub.pl

tel. 814486900 